\title{
Assessment of LLLT systemic effects on thyroid hormones function after dental titanium implant installation: An experimental rabbit model
}

\author{
Luciano Mayer $^{1 \#}$, Fernando Vacilotto Gomes ${ }^{2}$, Carlos Eduardo Baraldi \\ João Batista Blessmann Weber ${ }^{1}$, Marília Gerhardt de Oliveira ${ }^{3}$ \\ ${ }^{1}$ Department of Oral and Maxillofacial Surgery, School of Dentistry, Pontifícia Universidade Católica do Rio Grande do Sul, Porto \\ Alegre, Brazil; ${ }^{\#}$ Corresponding Author: contato@clinicamayer.com.br \\ ${ }^{2}$ Oral and Maxillofacial Surgery and Traumatology_-Department of Surgery, Universidade Federal do Rio Grande do Sul, School of \\ Dentistry, Rio Grande do Sul, Brazil \\ ${ }^{3}$ Oral and Maxillofacial Surgery Service, Hospital Cristo Redentor-Grupo Hospitalar Conceição, Porto Alegre, Brazil
}

Received 15 May 2013; revised 15 June 2013; accepted 23 June 2013

Copyright (C) 2013 Luciano Mayer et al. This is an open access article distributed under the Creative Commons Attribution License, which permits unrestricted use, distribution, and reproduction in any medium, provided the original work is properly cited.

\section{ABSTRACT}

This study aimed to assess the systemic effect of LLLT on thyroid gland functioning and consequently on calcium regulation through Triiodothyronine $\left(T_{3}\right)$ and Thyroxine $\left(T_{4}\right)$ measurements in rabbits' serum. A total of thirty two New Zealand male rabbits were randomly distributed in four groups with eight animals each: control group C (nonirradiated animals), group EI (5 $\mathrm{J} / \mathrm{cm}^{2}$ per session), group EII $\left(10 \mathrm{~J} / \mathrm{cm}^{2}\right.$ per session) and group EIII (20 J/cm ${ }^{2}$ per session). All animals underwent lower left incisor extraction followed by immediate insertion of an osseintegrated implant, providing an equality of initial clinical condition between the groups. The experimental groups were irradiated with aluminium gallium arsenide diode laser (GaAlAs, $\lambda=$ $830 \mathrm{~nm}, 50 \mathrm{~mW}, \mathrm{CW}$ ), during 13 days at each 48 hours, totalizing 7 sessions. Laboratorial $T_{3}$ and $\mathrm{T}_{4}$ measurements were done in four distinct moments (before surgical procedure, immediately after surgical procedure, after the first LLLT session and after the last LLLT session) in all animals. The results obtained showed statistically significant differences in Triiodothyronine values between the groups throughout the experiment. It was concluded that the LLLT, in the protocol of irradiation used in this study, promoted a significantly alteration on rabbits' serum hormonal levels.

*Financing: CNPq (National Council for Scientific and Technological Development); FIPE-UFRGS (Research and Event Incentive Fund).
Keywords: Thyroid Gland; Laser Therapy; Low Level; Thyroid Hormones; Dental Implant

\section{INTRODUCTION}

The devices of laser radiation are widely used by health care professionals, mostly for therapeutic uses and complementary diagnosis. Especially in Dentistry, the use of laser with different wavelengths and in distinct uses allowed the application of this technology in most diverse clinical procedures [1-3].

The clinical use of LLLT (low level laser therapy) is grounded on its capacity of promoting stimulating effects, at cellular level, on the biochemical and molecular processes that occur during the intrinsic mechanisms of tissue repair. Among the therapeutic effects, it can mention the increase of fibroblast proliferation, epithelial proliferation and collagen synthesis, which promotes the acceleration of the wound healing process; the functional neural recovery after injury; the hormone function regulation; the increased potential for remodeling and bone repair; reducing inflammation and edema; immune system regulation; modulation and relief of pain symptoms; besides post-operative analgesia [4-11].

Related literature presents several studies in vivo and in vitro which report the LLLT beneficial effects on repair process in animal models and tissue culture [10, 12-14]. According to some authors [15], the irradiation dose is the most important parameter in laser therapy and, even so, there is still no definitive protocol for its use in different clinical situations, which makes these parameters a matter of literature discussion [16,17-25] (Table 1). 
Table 1. Therapeutical lower level laser (LLLT) protocols used in previous studies.

\begin{tabular}{|c|c|c|c|c|c|c|c|c|c|}
\hline Author & Year & Laser type & Animal model & Sample & $\begin{array}{l}\text { Wave-lenght } \\
(\eta \mathrm{m})\end{array}$ & Power $(\mathrm{mW})$ & $\begin{array}{c}\text { Dose } / \text { Session } \\
\left(\mathrm{J} / \mathrm{cm}^{2}\right)\end{array}$ & $\begin{array}{c}\text { Total dose } \\
\left(\mathrm{J} / \mathrm{cm}^{2}\right)\end{array}$ & $\begin{array}{l}\text { Total of } \\
\text { sessions }\end{array}$ \\
\hline Pinheiro et al. [22] & 2003 & Infrared & Rabbit & 14 & 830 & 10 & 86 & 602 & 7 \\
\hline Khadra et al. [20] & 2004 & Infrared & Rabbit & 12 & 830 & 150 & 27 & 270 & 10 \\
\hline Lopes et al. [21] & 2005 & Infrared & Rabbit & 14 & 830 & 10 & 86 & 602 & 7 \\
\hline Jakse et al. [25] & 2007 & Infrared & Sheep & 12 & 680 & 75 & 4 & 12 & 3 \\
\hline Kim et al. [23] & 2007 & Infrared & Rat & 20 & 830 & 96 & 6.75 & 40.32 & 7 \\
\hline Kim et al. [24] & 2007 & Infrared & Rat & 20 & 830 & 96 & 6.75 & 40.32 & 7 \\
\hline Lopes et al. [19] & 2007 & Infrared & Rabbit & 14 & 830 & 10 & 86 & 602 & 7 \\
\hline Pereira et al. [18] & 2009 & Infrared & Rabbit & 12 & 780 & 70 & 52.5 & 367.5 & 7 \\
\hline Campanha et al. [17] & 2010 & Infrared & Rabbit & 30 & 830 & 10 & 86 & 602 & 7 \\
\hline Maluf et al. [16] & 2010 & Infrared & Rat & 24 & 795 & 120 & 8 & 48 & 6 \\
\hline
\end{tabular}

The laser biomodulation effects promotion on the site of its application may equally occur on tissues at a distance from the irradiation point [26]. So, when a LLLT is performed, distant organs from the application site may be affected, being these effects are called "systemics effects". Literature suggests that LLLT may reflect on endocrine functions, from possible laser effects on secretory glands [27], among them, the thyroid gland, which secretes important metabolism regulating hormonesTriiodothyronine and Thyroxine [28].

Previous studies about infrared laser irradiation on the thyroid gland showed temporary hyperactivity in some follicles and increased mitotic activity of follicular cells $[29,30]$ and, therefore, alterations in hormone levels of Triiodothyronine $\left(\mathrm{T}_{3}\right)$ and Thyroxine $\left(\mathrm{T}_{4}\right)$ [31].

The present study aimed to assess the systemic effect of LLLT on thyroid gland functioning, by measuring the amount of Triiodothyronine $\left(\mathrm{T}_{3}\right)$ and Thyroxine $\left(\mathrm{T}_{4}\right)$ present in rabbits' serum after laser application as an auxiliary therapy on osseointegration of immediate implants placed in fresh extraction sockets.

\section{MATHERIALS AND METHODS}

\subsection{Animals}

Thirty-two New Zealand male rabbits (Oryctolagus cuniculus) were used, weighing $3-4 \mathrm{~kg}$ and aged 3 months. They were distributed randomly in four different groups of 8 rabbits, being three groups assigned as experimentals (EI, EII and EIII) and one as control (Cnonirradiated animals). The animals were fed with solid diet $\left(\right.$ Purina $\left.^{\circledR}\right)$ and water ad libitum during all the experiment. They were kept in a climate-controlled environment, under normal conditions of light, humidity and temperature. Rabbits from the experimental groups (EI, EII and EIII) and control group (C) underwent lower left incisor surgical extraction and immediate placement of an osseointegrated implant, providing an equality of initial clinical condition between the four groups (Table 2).

\subsection{Surgical Procedure}

The animals were anesthetized by intramuscular injection of ketamine hydrochloride (Dopalen ${ }^{\circledR}$, Vetbrands Animal Health, São Paulo, SP), at a dose of $40 \mathrm{mg} / \mathrm{kg}$ and xylazine hydrochloride (Anasedan ${ }^{\circledR}$, Vetbrands Animal Health, São Paulo, SP), at $3 \mathrm{mg} / \mathrm{kg}$. Antisepsis was performed in the area of the lower left incisor with chlorhexidine gluconate $2 \%$ (FGM dental products), infiltration of $0.5 \mathrm{~mL}$ of $2 \%$ lidocaine with 1:100,000 epinephrine for a local vasoconstriction (Figure 1A) and, soon after, the incisor extraction with the aid of a pediatric forceps No. 5 (Edlo S/A, Canoas, Brazil) (Figure 1B). After that, the implant socket was prepared with sequentially sized drills (under copious irrigation with physiological saline) according to the sequence recommended by the manufacturer allowing the insertion of a nanoparticle-treated-surface osseointegrated implant $(3.25 \varnothing \times$ $11.5 \mathrm{~mm}$, Implant NanoTite ${ }^{\circledR}$, Biomet3i, Florida, USA) on that prepared socket (Figures 1C and D). The wound was closed with 4-0 nylon monofilament (Ethicon ${ }^{\mathbb{R}}$, Johnson \& Johnson) (Figure 1E). At the end of the procedure was performed trichotomy and marking with a dermographic pen $\left(\operatorname{Codman}^{\circledR}\right.$, Johnson \& Johnson, New Jersey, EUA) on the area corresponding to the long axis of the implant, in order to facilitate the identification of the site of laser irradiation (Figure 1F). Immediately after surgical procedure and 24 hours after this, the animals received analgesic therapy with Tramadol ${ }^{\mathbb{B}}$ (IM at a dose of $5 \mathrm{mg} / \mathrm{kg}$ ); as well as antimicrobial therapy with Enrofloxacin $^{\circledR}$ (IM, at a dose of $5 \mathrm{mg} / \mathrm{kg}$, once a day during 3 days). 
Table 2. Study parameters.

\begin{tabular}{|c|c|c|c|c|}
\hline & Control group & & Experimental groups & \\
\hline & $\mathrm{C}$ group & EI group & EII group & EIII group \\
\hline & $(\mathrm{n}=8)$ & $(\mathrm{n}=8)$ & $(\mathrm{n}=8)$ & $(\mathrm{n}=8)$ \\
\hline Surgical extraction & Left mand. incisor & Left mand. incisor & Left mand. incisor & Left mand. incisor \\
\hline Dental implant insertion & yes & yes & yes & yes \\
\hline Light source type & - & Laser (AlGaAs) & Laser (AlGaAs) & Laser (AlGaAs) \\
\hline Average power (mW) & - & 50 & 50 & 50 \\
\hline Wavelength (nm) & - & 830 & 830 & 830 \\
\hline Pulse parameters & - & $\mathrm{CW}$ & $\mathrm{CW}$ & $\mathrm{CW}$ \\
\hline Irradiation points & 0 & 2 & 2 & 2 \\
\hline No. applications per point & 0 & 1 & 1 & 1 \\
\hline Energy per point $\left(\mathrm{J} / \mathrm{cm}^{2}\right)$ & 0 & 2.5 & 5 & 10 \\
\hline Total energy density $\left(\mathrm{J} / \mathrm{cm}^{2}\right)$ & 0 & 5 & 10 & 20 \\
\hline Irradiation time/point (s) & 0 & 51 & 101 & 201 \\
\hline Total dose $\left(\mathrm{J} / \mathrm{cm}^{2}\right)$ & 0 & 35 & 70 & 140 \\
\hline
\end{tabular}

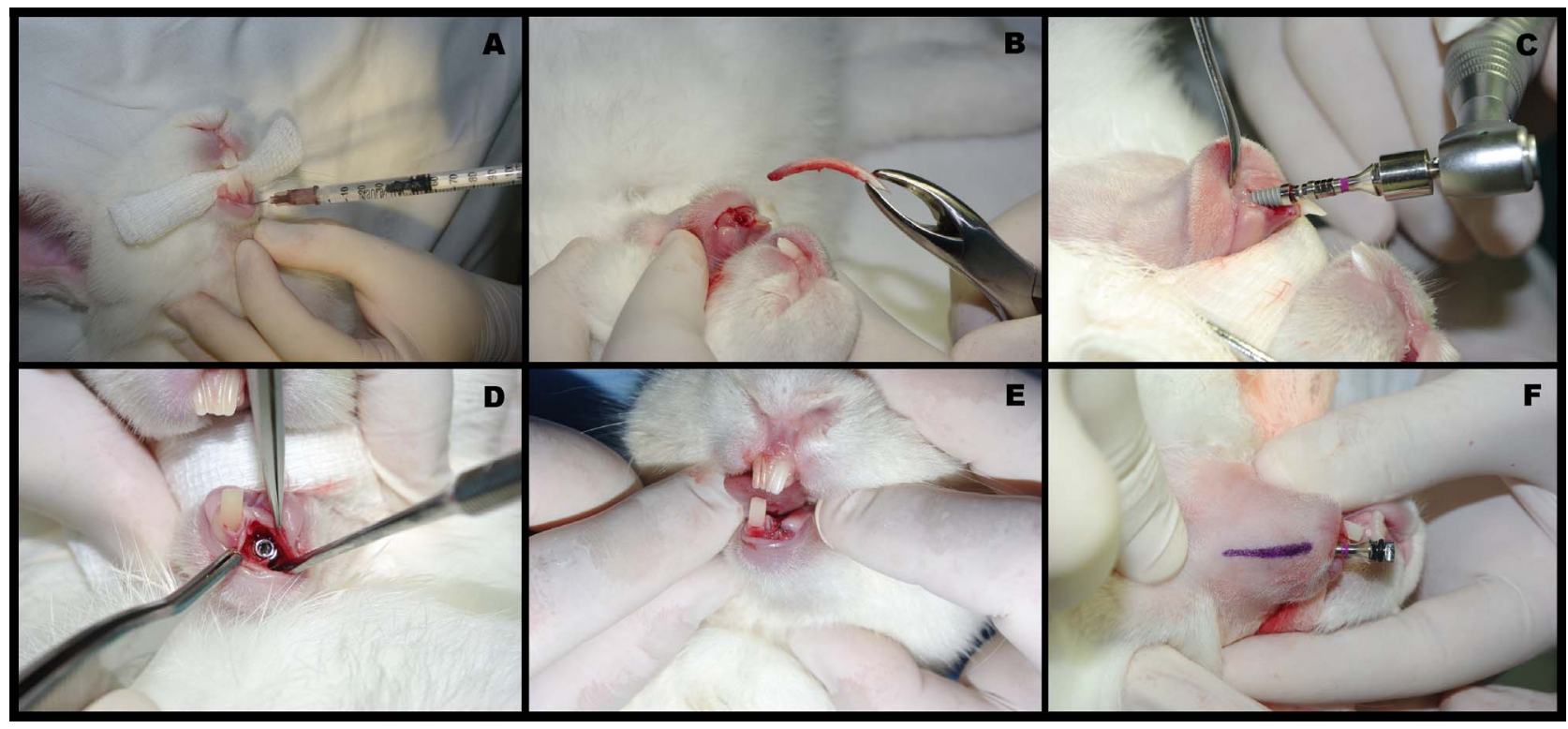

Figure 1. Surgical procedure: A) Infiltration with $0.5 \mathrm{~mL}$ lidocaine $2 \%$ with epinephrine $1: 100.000$; B) Extraction of left mandibular incisor through pediatric forceps no. 5; C) Insertion of an osseointegrated implant $3.25 \varnothing \times 11.5 \mathrm{~mm}$ (NanoTite ${ }^{\mathbb{B}}$ ) into the fresh extraction socket; D) Occlusal view after implant insertion; E) Suture with mononylon 4-0; F) Long axis of the implant demarcated in order to guide the application of LLLT.

\subsection{Laser Irradiation}

Laser therapy was performed with a GaAlAs infrared diode laser [16-25], wavelenght of $830 \mathrm{~nm}$ [17,19-24], in continuous emission mode and $50 \mathrm{~mW}$ power (Thera Lase $^{\circledR}$ —DMC Equipament, São Carlos, Brazil) in animals of the experimental groups (EI, EII and EIII) imme- diately after surgery. Irradiation was performed in intervals of 48 hours, totalizing 7 application/sessions in a period of 13 days. The doses per session were fractionated on 2 points - one medial and one lateral marking the long axis of the implant (Figure 1F). The laser probe was oriented perpendicularly to the underlying jaw, not overlapping implants in order to avoid reflection on the 
titanium surface. The nonirradiated animals (control group C) were subjected to a simulation of irradiation with the laser device unpowered, going through the same routine of irradiated animals.

The animals belonging to group EI received a total dose of $35 \mathrm{~J} / \mathrm{cm}^{2}-2.5 \mathrm{~J} / \mathrm{cm}^{2}$ per point, totalizing $5 \mathrm{~J} / \mathrm{cm}^{2}$ per session, applied in 51 seconds in each point (time adjustment was performed by the laser unit after determining the other parameters). Animals from group EII received a total dose of $70 \mathrm{~J} / \mathrm{cm}^{2}-5 \mathrm{~J} / \mathrm{cm}^{2}$ per point, totalizing $10 \mathrm{~J} / \mathrm{cm}^{2}$ per session, applied in 101 seconds in each point. Animals from group EIII received a total dose of $140 \mathrm{~J} / \mathrm{cm}^{2}$, being $20 \mathrm{~J} / \mathrm{cm}^{2}$ per session, applied in 201 seconds (Figure 2A and Table 2).

\subsection{Laboratory Tests}

The Triiodothyronine $\left(\mathrm{T}_{3}\right)$ and Thyroxine $\left(\mathrm{T}_{4}\right)$ measurements were performed in all animals from the four groups in four distinct moments: Time $1-72$ hours before dental extraction/implant placement, Time 2-immediately after surgery, Time $3-72$ hours after the first
LLLT session, and Time 4-72 hours after the last LLLT session. In order to perform these tests $3 \mathrm{~mL}$ of blood was collected by venipuncture of the jugular vein (Figure 2B). The blood collected was placed in appropriate Vacutainer $^{\mathrm{TM}}$ tubes (BD-Vacutainer ${ }^{(}$, Pediatric Systems, Becton \& Dickinson Co. Franklin Lakes, NJ, USA), without anticoagulant and sent under refrigeration, to the Veterinary Clinical Chemistry Laboratory, Universidade Federal do Rio Grande do Sul (LacVet-UFRGS, Porto Alegre, Brazil) in order to test hormone levels of Triiodothyronine $\left(\mathrm{T}_{3}\right)$ measured in ng/dL and Thyroxine $\left(\mathrm{T}_{4}\right)$ measured in $\mu \mathrm{g} / \mathrm{dL}$ present in serum of rabbits (Table 3 ) .

\subsection{Statistical Analysis}

The statistical analysis was performed using software SPSS $^{\circledR}$, version 17.0 (Statistical Package for Social Science, Chicago, USA) and software $\mathrm{SAS}^{\circledR}$, version 8.0 (Statistical Analysis System, SAS Institute Inc., Cary, $\mathrm{NC}, \mathrm{USA})$ and a $5 \%(\mathrm{p} \leq 0.05)$ maximum significance level was set. The laboratory values obtained for each animal/group were compared through repeated measures

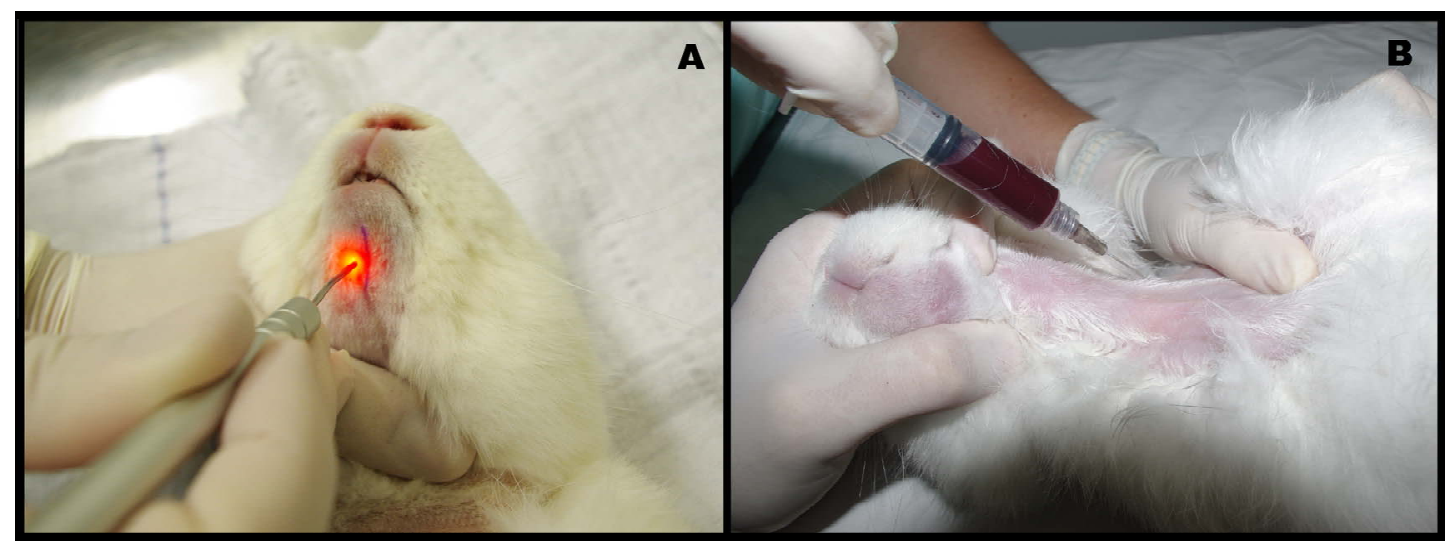

Figure 2. A) Application of LLLT. B) $3 \mathrm{~mL}$ of blood collection by venipuncture of the jugular vein.

Table 3. Statistical analysis: hormone levels of $\mathrm{T}_{3}$ and $\mathrm{T}_{4}$ measurement. Baseline levels expressed as mean \pm standard deviations. Means followed by different uppercase superscript letters across the same row denote significant differences. Means followed by different lowercase superscript letters across the same column denote significant differences on repeated measures analysis of variance (ANOVA) with Tukey's multiple comparisons test, for a significance level of $5 \%(\mathrm{p} \leq 0.05)$.

\begin{tabular}{|c|c|c|c|c|c|}
\hline & Groups & Time 1 & Time 2 & Time 3 & Time 4 \\
\hline \multirow{4}{*}{$\begin{array}{c}\text { Triiodothyronine } \\
\mathrm{T}_{3}\end{array}$} & $\mathrm{C}$ group $-0 \mathrm{~J} / \mathrm{cm}^{2}$ & $143.07 \pm 17.42^{\mathrm{B}-\mathrm{a}}$ & $168.98 \pm 23.19^{\mathrm{AB}-\mathrm{a}}$ & $181.57 \pm 23.63^{\mathrm{AB}-\mathrm{a}}$ & $198.64 \pm 52.62^{\mathrm{A}-\mathrm{ab}}$ \\
\hline & EI group $-35 \mathrm{~J} / \mathrm{cm}^{2}$ & $144.32 \pm 13.34^{\mathrm{A}-\mathrm{a}}$ & $175.64 \pm 25.15^{\mathrm{A}-\mathrm{a}}$ & $179.23 \pm 40.07^{\mathrm{A}-\mathrm{a}}$ & $163.02 \pm 22.85^{\mathrm{A}-\mathrm{b}}$ \\
\hline & EII group $-70 \mathrm{~J} / \mathrm{cm}^{2}$ & $163.42 \pm 26.86^{\mathrm{B}-\mathrm{a}}$ & $193.90 \pm 28.62^{\mathrm{AB}-\mathrm{a}}$ & $165.68 \pm 43.81^{\mathrm{B}-\mathrm{a}}$ & $223.86 \pm 40.26^{\mathrm{A}-\mathrm{a}}$ \\
\hline & EIII group $-140 \mathrm{~J} / \mathrm{cm}^{2}$ & $166.72 \pm 39.68^{\mathrm{A}-\mathrm{a}}$ & $182.80 \pm 19.05^{\mathrm{A}-\mathrm{a}}$ & $185.94 \pm 38.77^{\mathrm{A}-\mathrm{a}}$ & $196.96 \pm 52.35^{\mathrm{A}-\mathrm{ab}}$ \\
\hline \multirow{4}{*}{$\begin{array}{c}\text { Thyroxine } \\
\mathrm{T}_{4}\end{array}$} & $\mathrm{C}$ group $-0 \mathrm{~J} / \mathrm{cm}^{2}$ & $2.30 \pm 0.56^{\mathrm{B}-\mathrm{a}}$ & $3.03 \pm 0.56^{\mathrm{AB}-\mathrm{a}}$ & $2.69 \pm 0.66^{\mathrm{AB}-\mathrm{a}}$ & $3.18 \pm 0.65^{\mathrm{A}-\mathrm{a}}$ \\
\hline & EI group $-35 \mathrm{~J} / \mathrm{cm}^{2}$ & $2.19 \pm 0.73^{\mathrm{B}-\mathrm{a}}$ & $3.05 \pm 0.79^{\mathrm{A}-\mathrm{a}}$ & $3.29 \pm 0.92^{\mathrm{A}-\mathrm{a}}$ & $3.07 \pm 0.47^{\mathrm{A}-\mathrm{a}}$ \\
\hline & EII group $-70 \mathrm{~J} / \mathrm{cm}^{2}$ & $2.40 \pm 0.83^{\mathrm{A}-\mathrm{a}}$ & $2.73 \pm 0.85^{\mathrm{A}-\mathrm{a}}$ & $2.75 \pm 0.79^{\mathrm{A}-\mathrm{a}}$ & $3.12 \pm 0.84^{\mathrm{A}-\mathrm{a}}$ \\
\hline & EIII group $-140 \mathrm{~J} / \mathrm{cm}^{2}$ & $2.75 \pm 0.82^{\mathrm{A}-\mathrm{a}}$ & $3.29 \pm 0.93^{\mathrm{A}-\mathrm{a}}$ & $3.39 \pm 1.20^{\mathrm{A}-\mathrm{a}}$ & $3.37 \pm 0.71^{\mathrm{A}-\mathrm{a}}$ \\
\hline
\end{tabular}


analysis of variances (ANOVA), complemented by Tukey's post-hoc multiple comparisons test.

\section{RESULTS}

This study attempted to assess the systemic effect of LLLT in thyroid gland function through measurement of serum levels of Triiodothyronine $\left(\mathrm{T}_{3}\right)$ and Thyroxine $\left(\mathrm{T}_{4}\right)$ in blood samples serially collected. Tests were carried out on collected samples in four different moments throughout the experiment, allowing this way the comparison between the groups. Features of each one of the samples are expressed as absolute frequencies (nominal variables), averages and standard deviations (Figures 3 and 4). Level of significance was set in 5\% $(\mathrm{p}<0.05)$ for all analyses.

Evaluating separately the values found for each one of the studied laboratory tests, it's observed that Triiodothyronine $\left(\mathrm{T}_{3}\right)$ countings presented significant variations when taking into consideration the low level laser therapy (LLLT), but throughout the experiment (Table 3).

\section{DISCUSSION}

A rabbit model was chosen, as in some previous investigations [17-22], by the easiness of animal handling, surgical preparation and mostly by the animal proper size which enabled the insertion of standard implants (the same as used in humans) besides the collection of necessary volume blood for laboratory tests, unlikely from rat

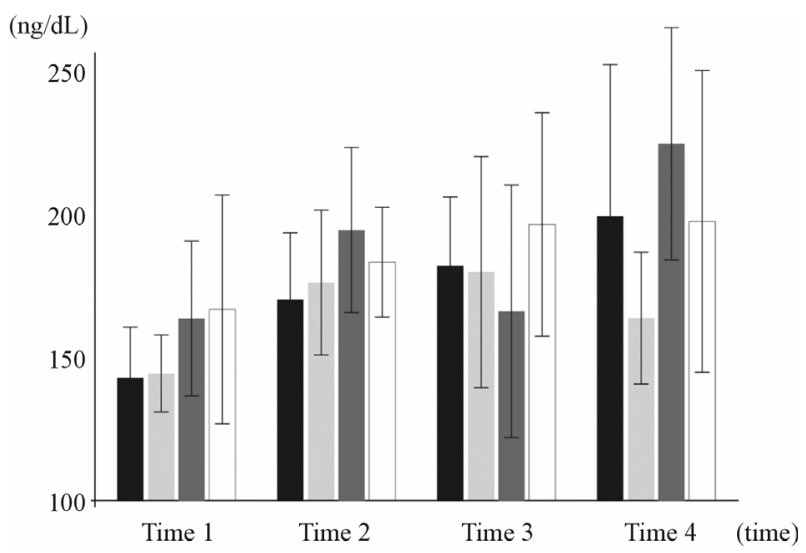

Figure 3. Triiodothyronine $\left(\mathrm{T}_{3}\right)$ hormone dosage variation presented in $\mathrm{ng} / \mathrm{dL}$ - Bars represent, respectively, control group $\mathrm{C}$ (BLAC BAR-Pre-op $143.07 \pm 17.42$; Trans-op $168.98 \pm$ 23.19; Post-op $181.57 \pm 23.63$; Post-LLLT $198.64 \pm 52.62)$ and each one of the experimental groups: Group EI $=35 \mathrm{~J} / \mathrm{cm}^{2}$ (LIGHT GRAY BAR-Pre-op 144.32 \pm 13.34; Trans-op $175.64 \pm 25.15$; Post-op 179.23 \pm 40.07; Post-LLLT $163.02 \pm$ 22.85). Group EII $=70 \mathrm{~J} / \mathrm{cm}^{2}$ (DARK GRAY BAR-Pre-op $163.42 \pm 26.86$; Trans-op $193.90 \pm 28.62$; Post-op $165.68 \pm$ 43.81; Post-LLLT $223.86 \pm 40.26$ ). Group EIII $=140 \mathrm{~J} / \mathrm{cm}^{2}$ (WHITE BAR-Pre-op $166.72 \pm 39.68$; Trans-op $182.80 \pm$ 19.05; Post-op $185.94 \pm 38.77$; Post-LLLT $196.96 \pm 52.35$ ).

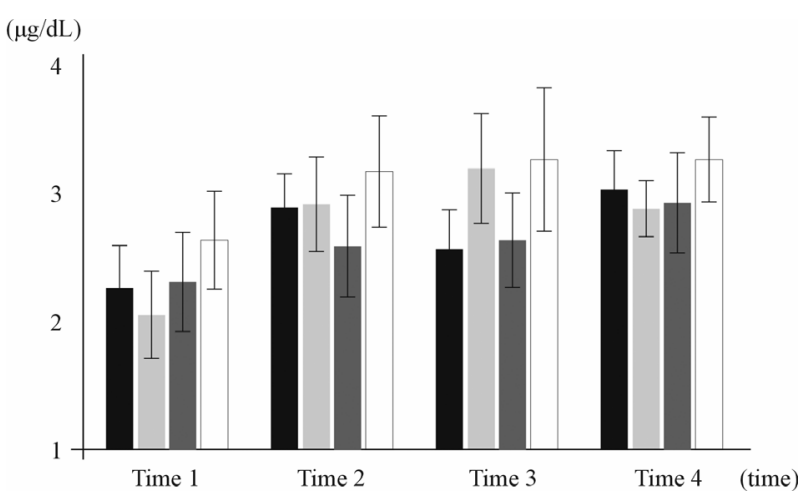

Figure 4. Thyroxine $\left(\mathrm{T}_{4}\right)$ hormone dosage variation presented in $\mu \mathrm{g} / \mathrm{dL}$ - Bars represent, respectively, control group C (BLAC BAR-Pre-op $2.30 \pm 0.56$; Trans-op $3.03 \pm 0.56$; Post-op 2.69 \pm 0.66 ; Post-LLLT $3.18 \pm 0.65)$ and each one of the experimental groups: Group EI $=35 \mathrm{~J} / \mathrm{cm}^{2}$ (LIGHT GRAY BARPre-op $2.19 \pm 0.73$; Trans-op $3.05 \pm 0.79$; Post-op $3.29 \pm 0.92$; Post-LLLT $3.07 \pm 0.47$ ). Group EII $=70 \mathrm{~J} / \mathrm{cm}^{2}$ (DARK GRAY BAR-Pre-op $2.40 \pm 0.83$; Trans-op $2.73 \pm 0.85$; Post-op 2.75 \pm 0.79; Post-LLLT $3.12 \pm 0.84$ ). Group EIII $=140 \mathrm{~J} / \mathrm{cm}^{2}$ (WHITE BAR-Pre-op $2.75 \pm 0.82$; Trans-op $3.29 \pm 0.93$; Post-op $3.39 \pm 1.20$; Post-LLLT $3.37 \pm 0.71$ ).

or mouse $[16,23,24]$, that due to their small size, it would be difficult to perform the proposed methodology. Regarding the placement of the implant in the alveolar area of the recently extracted incisor, it was chosen this area over the tibia in order to be nearest to the human clinical situation. Moreover, this method allowed more reliability, since the alveolar mandibular bone suffer a different load of the rabbits' tibia [32]. Likewise, accordingly with recent literature, we used the LLLT infrared spectrum [16-25], $830 \mathrm{~nm}$ wavelength [17,19-25], $50 \mathrm{~mW}$ power, 2 points laser application close to dental implants (without overlaying) on the animal lower jaws. It was performed a total of seven laser irradiation sessions $[17,19,21$, 22] with every 48 hours intervals and using different doses for each experimental group. The control group (sham group) did not receive any dose of LLLT, only the simulation of this was the method chosen in order to evaluate the laser systemic effects, not being possible such assessment in split-mouth studies [3] or a subject-as-own-control design [18].

LLLT has been shown to be effective and beneficial in several dental treatments. However, due to the wide use of laser by professionals and the lack of a well-defined protocol to the different kinds of treatment, the effects of LLLT on anatomical structures and their clinical applications have been studied by researchers; among the numerous indications of LLLT reported in the literature, it can be included the use in wounds healing in skin tissue $[7,10,13,26,33]$, use in post-extraction sockets $[1,4,6]$, regeneration of nerve tissue $[9,26]$ and use in perimplant tissue repair after implant placement [3,16-25]. 
In order to obtain an initial clinical condition for using laser in this experiment, it was performed the mandibular left incisor extraction and the insertion of an osseointegrated implant with the same surgical technique and by the same operator. Likewise, the choice of the anterior region of the mandible was based on the fact that when laser is applied on this location it could lead to indirect exposure of the thyroid gland, since that the application of laser in a well-defined area can affect deeper areas, presenting both a local and systemic effect $[26,33,34]$.

Some authors reported that after thyroid gland laser irradiation, some morphological and functional changes occur $[29,31,35]$. These findings stimulated this research, since thyroid is located next to the mandibular region being potentially irradiated in many dental procedures. However, it could be verified that in this research format, LLLT altered the $\mathrm{T}_{3}$ as a result of the treatment. Therefore, it's observed that there was LLLT influence on the thyroid hormone levels action, as well as the elapsed time throughout the experiment.

Thus, the possibility of LLLT systemic effects [26,33] with distance site application on photobiomodulation action, the sample was divided into separate distinct control and experiment groups. In disagreement with some works that used in the same animal one side as control and the other as experiment $[18,25]$ and in humans, split-mouth studies [3], it was verified that these works suggested that the experimental side was similar to the control side when LLLT was used. It is not impossible that such results were influenced by the laser systemic action.

In this study, the diode laser GaAlAs $(\lambda=830 \mathrm{~nm})$ was used by its capacity of tissue penetration. Infrared lasers have higher penetration into subcutaneous tissues due to poor absorption by water or skin pigments $[1,2]$.

The thyroid gland function is usually assessed by measuring basal serum concentration of its hormones. The radioimmunoassay (RIA) is one of the methods used for hormone assays that have been used by researchers to measure the amount of Triiodothyronine $\left(\mathrm{T}_{3}\right)$ and Thyroxine $\left(\mathrm{T}_{4}\right)$ circulating in blood serum [12,35]. RIA is based on the observation of the reaction between antibodies and soluble antigen, forming a precipitate of antigen-antibody or an insoluble aggregate. Among its advantages are high sensitivity on antigens detection in small concentrations and convenience when lots of samples are tested together, reducing the amount of manual operations to be performed, facilitating the process of separation and reducing the chances of error [36].

The results of this study demonstrated significant differences in hormone levels of the thyroid gland after LLLT application, differing from Lerma et al. [35] findings, who analyzing the HeNe laser effects on Wistar rats thyroid glands, did not find any concrete evidence of alteration in thyroid hormones serum levels. The same way, Fronza et al. [34], demonstrated that in rabbits there is no significant difference between the control and experimental groups before and after irradiation by LLLT on blood values of $\mathrm{T}_{3}$ and $\mathrm{T}_{4}$, indicating that laser did not affect thyroid function on circulating serum hormone levels in rabbit model. Our results, however, confirm the findings of Azevedo et al. [12], who performed the application of LLLT $(\lambda=780 \mathrm{~nm})$ on Swiss mice thyroid glands. Authors observed significant differences in $T_{3}$ and $\mathrm{T}_{4}$ hormone levels from the first day of laser application and seventh day after the last application.

In order to verify the individual variability of the studied specimen, the same animal was subjected to measurements of $T_{3}$ and $T_{4}$ with and without laser therapy in distinct moments. Such methodology made possible the comparison of obtained values before, during and after administration of the LLLT protocol in each study group.

Also relevant is the fact that different protocols used in LLLT made difficult the interpretation of the effect of laser on thyroid gland function, as well as the compareson of results of other variables among the studies. We agree with Basford [2], Kolávorá et al. [37], Belkin and Schwartz [38] and Schindl et al. [39], which indicate the need for more well-defined protocols in the methodology of works in order to obtain more reliable comparisons, thus providing the correct conduction of studies that verify the real performance of laser on tissues, organs and systems.

New researches varying the animal's number, laser dosages and power settings, as well as the irradiation period, must be performed in order to better understand the effects of LLLT on this gland functioning.

\section{CONCLUSION}

In spite of having significantly alteration on Triiodothyronine $\left(T_{3}\right)$ hormone levels, the LLLT did not permanently affect the rabbit's thyroid gland function, in the irradiation protocol used in this study. However, this work showed irradiation distance action by altering the gland secretion. For these reason, it must be considered a special care on closely secretory glands LLLT application.

\section{ACKNOWLEDGEMENTS}

The authors would like to thank: The staff at the Veterinary Clinical Chemistry Laboratory, Universidade Federal do Rio Grande do Sul, particularly Dr. Viviane Marques Guyoti, DVM, and Dr. Félix H. D. González, DVM; the Animal Experimentation Unit, Hospital de Clínicas de Porto Alegre, Universidade Federal do Rio Grande do Sul, particularly Dr. Fabíola Schons Meyer, DVM, and Marta Justina Giotti Cioato, RN; Hospital de Clínicas de Porto Alegre for financial support through its Research and Event Incentive Fund (FIPE), which made 
possible the experimental portion of this study; and Prof. João Feliz de Moraes, ScD, of the PUCRS School of Mathematics, for his assistance with statistical analyses; and Fabricio Massotti DDS, Specialist, Oral and Maxillofacial Surgery and Traumatology; Master's Candidate, Oral and Maxillofacial Surgery and Traumatology_-Department of Surgery, Universidade Federal do Rio Grande do Sul (UFRGS) School of Dentistry, Rio Grande do Sul, Brazil.

\section{REFERENCES}

[1] Kucerová, H., Dostálová, T., Himmlova, L., Bártová, J. and Mazánek, J. (2000) Low level laser therapy after molar extraction. Journal of Clinical Laser Medicine and Surgery, 6, 309-315.

[2] Basford, J.R. (1995) Low intensity laser therapy: Still not an established clinical tool. Lasers in Surgery and Medicine, 4, 331-342. doi:10.1002/1sm.1900160404

[3] García-Morales, J.M., Tortamano-Neto, P., Todescan, F.F., de Andrade, J.C., Jr., Marotti, J. and Zezell, D.M. (2012) Stability of dental implants after irradiation with an 830nm low-level laser: A double-blind randomized clinical study. Lasers in Medical Science, 4, 703-711. doi:10.1007/s10103-011-0948-4

[4] Takeda, Y. (1988) Irradiation effect of low-energy laser on alveolar bone after tooth extraction: Experimental study in rats. International Journal of Oral and Maxillofacial Surgery, 6, 388-391. doi:10.1016/S0901-5027(88)80070-5

[5] Rigau, J., Trelles, M.A, Calderhead, R.G. and Mayayo, E. (1991) Changes in fibroblast proliferation and metabolism following "in vitro" helium-neon laser irradiation. Laser Therapy, 1, 25-33.

[6] Silva Jr., A.N., Pinheiro, A.L., Oliveira, M.G., Weismann, R., Ramalho, L.M. and Nicolau, R.A. (2002) Computerized morphometric assessment of the effect of low-level laser therapy on bone repair: An experimental animal study. Journal of Clinical Laser Medicine and Surgery, 2 , 83-87. doi:10.1089/104454702753768061

[7] do Nascimento, P.M., Pinheiro, A.L., Salgado, M.A. and Ramalho, L.M. (2004) A preliminary report on the effect of laser therapy on the healing of cutaneous surgical wounds as a consequence of an inversely proportional relationship between wavelength and intensity: Histological study in rats. Photomedicine and Laser Surgery, 6, 513518. doi:10.1089/pho.2004.22.513

[8] Weber, J.B., Pinheiro, A.L., de Oliveira, M.G., Oliveira, F.A. and Ramalho, L.M. (2006) Laser therapy improves healing of bone defects submitted to autologous bone graft. Photomedicine and Laser Surgery, 1, 38-44. doi:10.1089/pho.2006.24.38

[9] Mohammed, I.F., Al-Mustawfi, N. and Kaka, L.N. (2007) Promotion of regenerative processes in injured peripheral nerve induced by low-level laser therapy. Photomedicine and Laser Surgery, 2, 107-111. doi:10.1089/pho.2006.1090

[10] Soares, L.P., Oliveira, M.G., Pinheiro, A.L., Fronza, B.R. and Maciel, M.E. (2008) Effects of laser therapy on experimental wound healing using oxidized regenerated ce- lulose hemostat. Photomedicine and Laser Surgery, 1, 10-13. doi:10.1089/pho.2007.2115

[11] Freddo, A.L., Rodrigo, S.M., Massotti, F.P., Etges, A. and de Oliveira, M.G. (2009) Effect of low-level laser therapy after implantation of poly-L-lactic/polyglycolic acid in the femurs of rats. Lasers in Medical Science, 5, 721-728. doi:10.1007/s10103-008-0627-2

[12] Azevedo, L.H., de Paula Eduardo, F., Moreira, M.S., de Paula Eduardo, C. and Marques, M.M. (2006) Influence of different power densities of LILT on cultured human fibroblast growth: A pilot study. Lasers in Medical Science, 2, 86-89. doi:10.1007/s10103-006-0379-9

[13] Corazza, A.V., Jorge, J., Kurachi, C. and Bagnato, V.S. (2007) Photobiomodulation on the angiogenesis of skin wounds in rats using different light sources. Photomedicine and Laser Surgery, 2, 102-106. doi:10.1089/pho.2006.2011

[14] de Oliveira, R.F., Oliveira, D.A., Monteiro, W., Zangaro, R.A., Magini, M. and Soares, C.P. (2008) Comparison between the effect of low-level laser therapy and low-intensity pulsed ultrasonic irradiation in vitro. Photomedicine and Laser Surgery, 1, 6-9.

[15] Pinheiro, A.L. (2009) Advances and perspectives on tissue repair and healing. Photomedicine and Laser Surgery, 6, 833-836. doi:10.1089/pho.2009.2716

[16] Maluf, A.P., Maluf, R.P., Brito, C.R., França, F.M. and de Brito, R.B., Jr. (2010) Mechanical evaluation of the influence of low-level laser therapy in secondary stability of implants in mice shinbones. Lasers in Medical Science, $\mathbf{5}$, 693-698. doi:10.1007/s10103-010-0778-9

[17] Campanha, B.P., Gallina, C., Geremia, T., Loro, R.C., Valiati, R., Hübler, R. and de Oliveira, M.G. (2010) Low-level laser therapy for implants without initial stability. Photomedicine and Laser Surgery, 3, 365-369. doi:10.1089/pho.2008.2429

[18] Pereira, C.L., Sallum, E.A., Nociti, F.H., Jr. and Moreira, R.W. (2009) The effect of low-intensity laser therapy on bone healing around titanium implants: A histometric study in rabbits. The International Journal of Oral \& Maxillofacial Implants, 1, 47-51.

[19] Lopes, C.B., Pinheiro, A.L., Sathaiah, S., da Silva, N.S. and Salgado, M.A. (2007) Infrared laser photobiomodulation (lambda $830 \mathrm{~nm}$ ) on bone tissue around dental implants: A Raman spectroscopy and scanning electronic microscopy study in rabbits. Photomedicine and Laser Surgery, 2, 96-101. doi:10.1089/pho.2006.2030

[20] Khadra, M., Ronold, H.J., Lyngstadaas, S.P., Ellingsen, J.E. and Haanaes, H.R. (2004) Low-level laser therapy stimulates bone-implant interaction: An experimental study in rabbits. Clinical Oral Implants Research, 3, 325332. doi:10.1111/j.1600-0501.2004.00994.x

[21] Lopes, C.B., Pinheiro, A.L., Sathaiah, S., Duarte, J. and Cristinamartins, M. (2005) Infrared laser light reduces loading time of dental implants: A Raman spectroscopic study. Photomedicine and Laser Surgery, 1, 27-31. doi:10.1089/pho.2005.23.27

[22] Pinheiro, A.L.B., Lopes, C.B., Sathaiah, S. and Duarte, J. (2003) Laser biomodulation in bone implants: A Raman spectral study. International Congress Series, 1248, 449- 


\section{1. doi:10.1016/S0531-5131(03)00061-X}

[23] Kim, Y.D., Kim, S.S., Hwang, D.S., Kim, S.G., Kwon, Y.H., Shin, S.H., Kim, U.K., Kim, J.R. and Chung, I.K. (2007) Effect of low-level laser treatment after installation of dental titanium implant-immunohistochemical study of RANKL, RANK, OPG: An experimental study in rats. Lasers in Surgery and Medicine, 5, 441-450. doi:10.1002/1sm.20508

[24] Kim, Y.D., Kim, S.S., Hwang, D.S., Kim, S.G., Kwon, Y.H., Shin, S.H., Kim, U.K., Kim, J.R. and Chung, I.K. (2007) Effect of low-level laser treatment after installation of dental titanium implant-immunohistochemical study of vascular endotelial growth fator: An experimental study in rats. Laser Physics Letters, 9, 681-685. doi:10.1002/lapl.200710036

[25] Jakse, N., Payer, M., Tangl, S., Berghold, A., Kirmeier, R. and Lorenzoni, M. (2007) Influence of low-level laser treatment on bone regeneration and osseointegration of dental implants following sinus augmentation. An experimental study on sheep. Clinical Oral Implants Research, 4, 517-524. doi:10.1111/j.1600-0501.2007.01369.x

[26] Rochkind, S., Rousso, M., Nissan, M., Villarreal, M., Barr-Nea, L. and Rees, D.G. (1989) Systemic effects of low-power laser irradiation on the peripheral and central nervous system, cutaneous wounds and burns. Lasers in Surgery and Medicine, 2, 174-182. doi:10.1002/1sm.1900090214

[27] Smith-Agreda, V. (1985) Aportaciones al estudio de las interacciones morfoquímicas de las células adenohipofisarias tras la estimulación com laser $\mathrm{He} / \mathrm{Ne} 6328 \mathrm{~nm}$ de baja potencia. Clinical Laser, 1, 51-62.

[28] Fisher, D.A. (1996) Physiological variations in thyroid hormones: Physiological and pathophysiological considerations. Clinical Chemistry, 1, 135-139.

[29] Parrado, C., Peláez, A., Vidal, L. and Pérez de Vargas, I. (1990) Quantitative study of the morphological changes in thyroid gland following IR laser irradiation. Lasers in Medical Science, 77, 77-80. doi:10.1007/BF02032627

[30] Parrado, C., Albornoz, F.C., Vidal, L. and Pérez de Vargas, I. (1999) A quantitative investigation of microvascular changes in the thyroid gland after infrared (IR) laser radiation. Histology and Histopathology, 4, 1067-1071.

[31] Azevedo, L.H., Aranha, A.C., Stolf, S.F., Eduardo, C.P. and Vieira, M.M. (2005) Evaluation of low intensity laser effects on the thyroid gland of male mice. Photomedicine and Laser Surgery, 6, 567-570. doi:10.1089/pho.2005.23.567

[32] de Jong, W.C., Korfage, J.A. and Langenbach, G.E. (2010) Variations in habitual bone strains in vivo: Long bone versus mandible. Journal of Structural Biology, 3, 311-318. doi:10.1016/j.jsb.2010.06.013

[33] Rodrigo, S.M., Cunha, A., Pozza, D.H., Blaya, D.S., Moraes, J.F., Weber, J.B. and Oliveira, M.G. (2009) Analysis of the systemic effect of red and infrared laser therapy on wound repair. Photomedicine and Laser Surgery, 6, 929-935. doi:10.1089/pho.2008.2306

[34] Fronza, B., Somacal, T., Mayer, L., Moraes, J.F., Oliveira, M.G. and Weber, J.B. (2013) Assessment of the systemic effects of low-level laser therapy (LLLT) on thyroid hormone function in a rabbit model. International Journal of Oral and Maxillofacial Surgery, 1, 26-30. doi:10.1016/i.ijom.2012.06.017

[35] Lerma, E., Hevia, A., Rodrigo, P., Gonzalez-Campora, R., Armas, J.R. and Galera, H. (1991) The effect of HeNe laser radiation on the thyroid gland of the rat. International Journal of Experimental Pathology, 4, 379-385.

[36] Steinbeck, M.J. and Wyner, L.R. (1993) Immunoassay and Related Principles. In: Anderson, S.C. and Cockayne, S., Eds., Clinical Chemistry: Concepts and Applications, HBJ International, Saunders, Philadelphia, 96-99.

[37] Kolávorá, H., Ditrichová, D. and Wagner, J. (1999) Penetration of the laser light into the skin in vitro. Lasers in Surgery and Medicine, 3, 231-235.

[38] Belkin, M. and Schwartz, M. (1989) New biological phenomena associated with laser radiation. Health Physics, $\mathbf{5}$, 687-690. doi:10.1097/00004032-198905000-00014

[39] Schindl, A. (2000) Low-Intensity laser therapy: A review. Journal of Investigative Medicine, 5, 312-326. 